\title{
Damage by episodic flooding to Phragmites reeds in a prealpine lake: proposal of a model
}

\author{
Wolfgang Ostendorp \\ Limnologisches Institut, Universität Konstanz Postfach 5560, W-7750 Konstanz, Federal Republic of Germany
}

Received March 6, 1990 / Accepted in revised form October 25, 1990

Summary. The development of lakeside fringes of Phragmites reeds can be affected by high water levels, leading in extreme cases to die-back. A model is presented that allows estimation of the proportions of the damage. The model - formulated for 1 year and one Phragmites stalk is based on the growth curve of the stalk, the altitude of the growth site, and the water level curve for the year. Applied to a reed stand over a series of years, the model is based upon the frequency distribution of the critical stalk length and the chance that the water level will be below a given value, each parameter being time dependent. Three case studies from Lake Constance-Untersee provide an example of the significance of episodic high water levels. Hence, aestival high water levels are expected to be one of the main factors controlling the lakeside frontline of the reedbelt. The model can be used in waterworks engineering, where reed plantations are to be established on the shores of lakes and reservoirs with strongly fluctuating water levels.

Key words: Phragmites - Flooding sensitivity - Model Prealpine lakes

The common reed, Phragmites australis (Cav.) Trin. ex Steud. (Poaceae). is a perennial grass which colonises a wide range of habitats and substrates, provided that there is enough moisture in the subsoil. The most vigorous growth is achieved where the water table lies a few decimeters above the ground (Rodewald-Rudescu 1974).

There are few terrestrial plant species that tolerate such high and long-standing inundation as Phragmites, due to its anatomical and physiological features (see below). The flooding tolerance of the common reed is, however, limited: lakes and reservoirs with annual differences between high and low water levels of $3 \mathrm{~m}$ or more do not normally allow reed stands to grow on its shore. Even where the lake level fluctuations are less extreme, serious damage to the reed belt has been observed (Schwilch 1963; Rudescu 1965, pp 88-89; Rode-
wald-Rudescu 1974, pp 113-114; Ostendorp 1990), and attempts at reed plantation are often unsuccessful for the same reason (Peintinger 1987).

The measurements discussed below were taken in the lakeside reedbelts of Lake Constance-Untersee. Lake Constance is one of the few larger prealpine lakes without artificial lake level regulation. The lowest value is normally reached in February; the lake level then rises along with reed growth, until June or July, before dropping again. Great deviations from the average of the yearly patterns of the water level fluctuations are the rule rather than the exception.

Hence, the question arises whether the lakeside reed front is controlled by high water events, and whether the flooding tolerance can be modified by certain reed mangement techniques. The model presented here also aims to optimize reed plantations at the shore of lakes and reservoirs with strongly fluctuating water levels.

\section{Results}

Flooding sensitivity of Phragmites australis

Phragmites australis is a typical terrestrial plant as its leaves have stomata, well developed sclerenchyma and a thick cuticula. To photosynthetize and to accumulate assimilation products the leaves must not be submerged, as the $\mathrm{CO}_{2}$ diffusion rate in water is much lower than in air (Rodewald-Rudescu 1974, p 81). Similarly, oxygen transport from the culm or the leaves into the rhizomes is possible only if the plant is in contact with the atmosphere. Otherwise the plant will no longer be able to supply its rhizomes with sufficient oxygen to maintain aerobic respiration (Yamasaki and Tange 1981; Brändle and Crawford 1987). The stored oxygen within the aerenchyma and the central cavity of the rhizome is sufficient for only 1 or 2 days before anaerobic metabolism starts (Studer and Brändle 1984). Phragmites cannot stand anaerobic metabolism for long as glycolysis + alcoholic fermentation (a) produces a toxic metabolite, and (b) is 
very ineffective, yielding only 2 instead of 38 moles ATP per mole glucose. Hence large amounts of starch are needed (Brändle 1983, 1985), and in May and June, when the culms are growing vigorously, the flooding tolerance is expected to be at its lowest. Field observations in Lake Constance have shown that a few days after becoming submerged the leaves begin to turn yellow and later die down. In addition, presumably the ethylene produced in the anaerobic soil or in the lower parts of the plant is prevented from escaping freely into the atmosphere, thereby inducing leaf senescence (Etherington 1983).

Flooded stalks can elongate their internodes to escape submergence, but eventually their growth ceases and they die down. Consequently the rhizomes no longer receive any oxygen and must also die.

High water leads not only to interruption of oxygen transport, but often also to increased mechanical damage to the plant by waves and drifting matter. The stalks are drawn below water or are snapped off, and the effects described above are exacerbated.

\section{Growth characteristics of reed stalks}

The aboveground parts of the reed plant must grow anew each year. In the first half of the growth period, the new
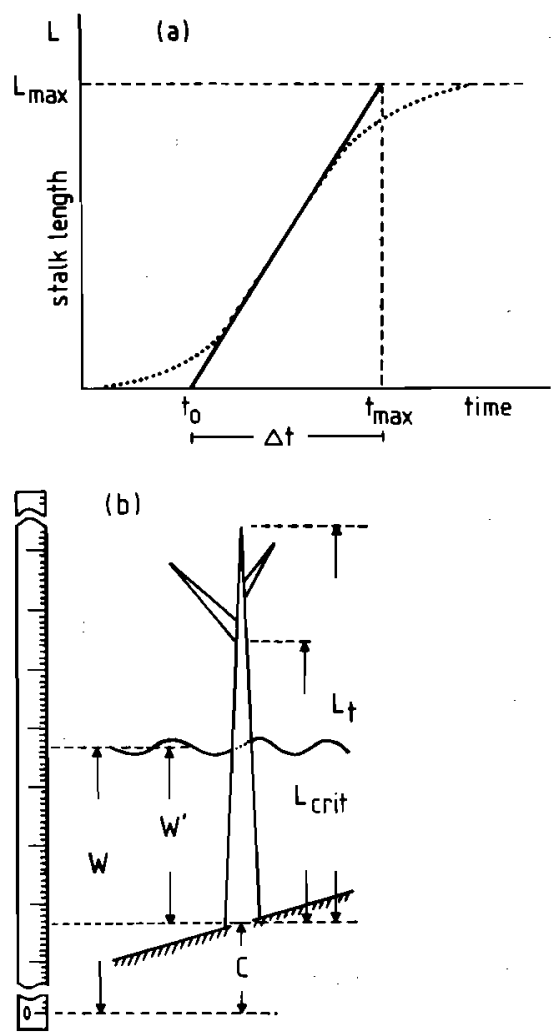

Fig. 1a. Growth curve of Phragmites stalks and the formal approximation. Dotted line - growth curve, solid line - approximation by a straight line; definition of $t_{0}$ - beginning of growth, $t_{\max }$ - end of growth, $\Delta t$ - duration of growth. b Definition of total length $\left(L_{t}\right)$, critical length $\left(L_{\text {crii }}\right)$ of a Phragmites stalk, the altitude of the place at which the stalk grows $(c)$ and the height of the water table above ground $\left(W^{\prime}\right)$ and above sea level $(W)$ growth is maintained by the rhizomes in which assimiliation products have been stored since the previous summer. The sprouting of the buds begins in the last third of April, when the temperature passes limiting values (Ostendorp, unpubl.). In the following 3 months the culms grow up with a constant growth rate $\dot{\mathbf{L}}$ and reach their final length $(1.5-5 \mathrm{~m})$ in the last half of July. The panicles are fully grown about 3 weeks later.

Hence, the growth of Phragmites from the beginning of May to mid July can easily be described by:

\section{$L(t)=\dot{\mathbf{L}} \cdot t+a$}

where $L$ is the length of the stalk from the ground to the top of the highest unexpanded leaf, $t$ is the time elapsed since the start of the year, $\dot{\mathbf{L}}$ is the constant growth rate and $a$ is the intercept (Fig. 1a). The beginning and end of growth, $t_{0}$ and $t_{\max }$ as well as the duration of growth $\Delta t=t_{\max }-t_{0}$ can be computed from the slope $\dot{L}$ and the intercept $a$. This graph fits the empirical data well: the correlation coefficient $r^{2}$ varies between 0.95 and 0.999 (individual stalks with $n=5-9$ measurements each). Using this model it is possible to estimate the length of a stalk for any time during the vegetation period.

\section{Critical conditions for reed growth}

The "critical conditions", i.e. the minimum duration and the minimum height of flooding that lead to injury of Phragmites plants, are not well known. In this study it is assumed that flooding lasting longer than 2 days leads to an oxygen deficiency in the rhizome and thereby stunts the reed's growth (I). But if the two uppermost leaves are never submerged, Phragmites would not be affected (II). If the young sprouts do not possess leaves at the early stage of their growth, the submergence is irrelevant, whatever its depth may be (III). We can approximate (I) by using the average water level of five succeeding days. Conditions (II) and (III) are fulfilled by defining a "critical" stalk length

$L_{\text {crit }}=L_{t}-m \cdot\left(L_{t}-L_{0}\right)^{n}$

where $L_{0}$ is the length of leafless sprouts in the early stage of their development, and $L_{t}$ is the total length (Fig. lb). In this study the coefficient $m$ has been found to be 8.97 , $n$ is 0.34 , and $L_{0}$ is $40 \mathrm{~cm}\left(n=49, r^{2}=0.906\right)$.

i.

\section{Dependence of the growth parameters on the basal diameter}

The stalk population of a reed stand is not homogenous. The variability can be described by the diameter at the stalk basis (basal diameter, $D_{b}$ ). Ostendorp and Möller (1991) demonstrated that at least two stalk types can be distinguished by means of the frequency distribution of $D_{b}$. Many growth parameters and morphological fea- 
Table 1. Significance of the basal diameter of a reed stalk for its growth (exemplified for reed stand (b), see Figs. 4 and 5 ); all correlation coefficients are significant at the $1 \%$ level; $D_{b}(\mathrm{~mm}), \dot{\mathbf{L}}\left(\mathrm{m}\right.$ day $\left.{ }^{-1}\right), L_{\max }(\mathrm{m}), t_{0}, \Delta t$ (days)

$\begin{array}{lrlrl}\text { Max. stalk length } & L_{\max } & =1.15+0.27 D_{b} & & n=29, r=0.904 \\ \text { Beginning of growth } & t_{0} & =144.5-1.63 D_{b} & n=47, r=-0.540 \\ \text { Duration of growth } & \Delta t=46.0+2.21 D_{b} & n=29, r=0.525 \\ \text { Mean growth rate } & \dot{\mathbf{L}}=3.26+0.23 D_{b} & n=47, r=0.570\end{array}$

tures are correlated with $D_{b}$ (Table 1). The within-stand variability must be considered if the extent of damage to a Phragmites stand is to be evaluated.

\section{Flooding events in relation to water level and growth curve}

Whether a reed stalk is submerged or not depends upon its length and the actual water level at time $t$ and upon the altitude $c$ of the place at which the stalk grows (Fig. 1b). The water level at a given date in the course of a year shows a great variability at Lake Constance. If many water level records are available one can compute, for any date of the year, the possibility that the water level will be above a given value, or the probability that a given water level will be reached. (Fig. 2). Hence, the possibility of a particular stalk with known growth parameters $\left(c, \dot{\mathbf{L}}, t_{0}\right)$ being flooded can be estimated. The time of the year at which this probability is highest is ascertained by the same procedure.

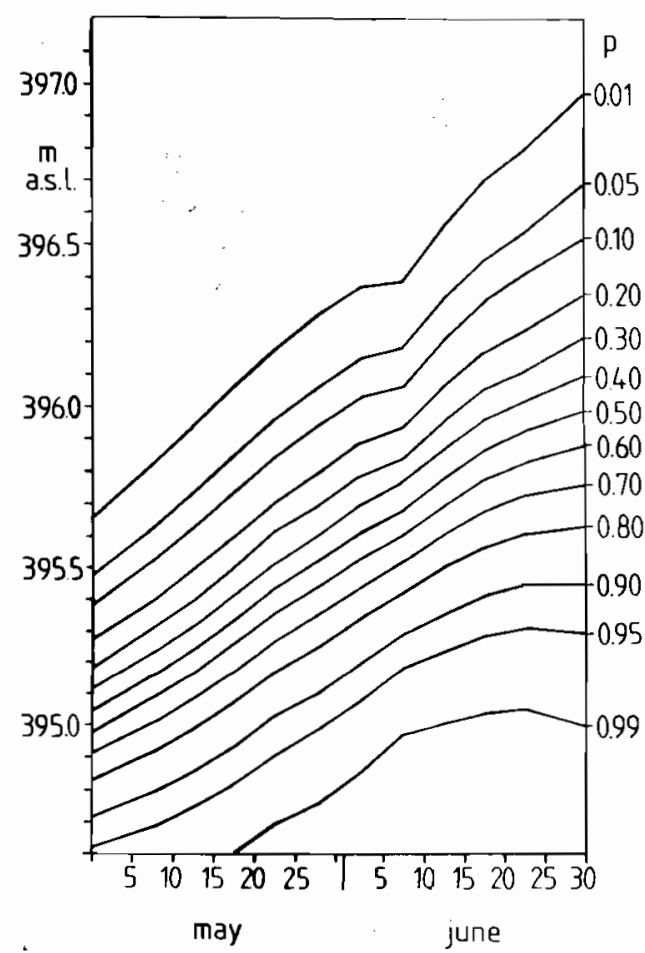

Fig. 2. Probability $p$ that a given water level will be reached (means of 5 or 6 days). Example: How great is the probability that a water level of $395.30 \mathrm{~m}$ a.s.l. will be reached on 31 May? $p$ is 0.80 , i.e. this water level is not reached on 31 May in only 1 out of 5 years on average

\section{Case studies}

\section{Die-back of reeds in Lake Constance-Untersee}

More than 35 lakes in Europe are affected by reed decline (Ostendorp 1989), among them Lake Constance-Untersee (Ostendorp 1990). There is controversy over the causal factors: Schröder $(1979,1987)$ has focused upon nutrient enrichment and eutrophication processes, whereas Lang (1968, pp 317-318) pointed out that "...das zeitweise Auftreten und die Dauer von Spitzenhochwässern in einzelnen Jahren eine Rolle spielen, denn der Schilfrückgang ist nach wiederholten Hochwasserjahren (1965, 1966) besonders augenscheinlich". ("...the occasional occurrence and duration of peak high water levels in individual years play a role, for the reed dieback is especially noticeable after repeated high water years e.g. 1965, 1966.") However, no detailed observations or investigations were carried out in these years.

The model allows to test this hypothesis (Fig. 3). Let us assume a Phragmites stand as it was before 1965 (as shown by mapping the "stubble fields" which are the last remains of the dead reedstands). The lakeside border of the reed belt is at an altitude of $394.35 \mathrm{~m}$ a.s.l., the stalks are tall and stout, with a mean growth rate of $4.0 \mathrm{~cm}$ day $^{-1}$ and a starting point for linear growth of $t_{0}=110$ days (i.e. 20 April).

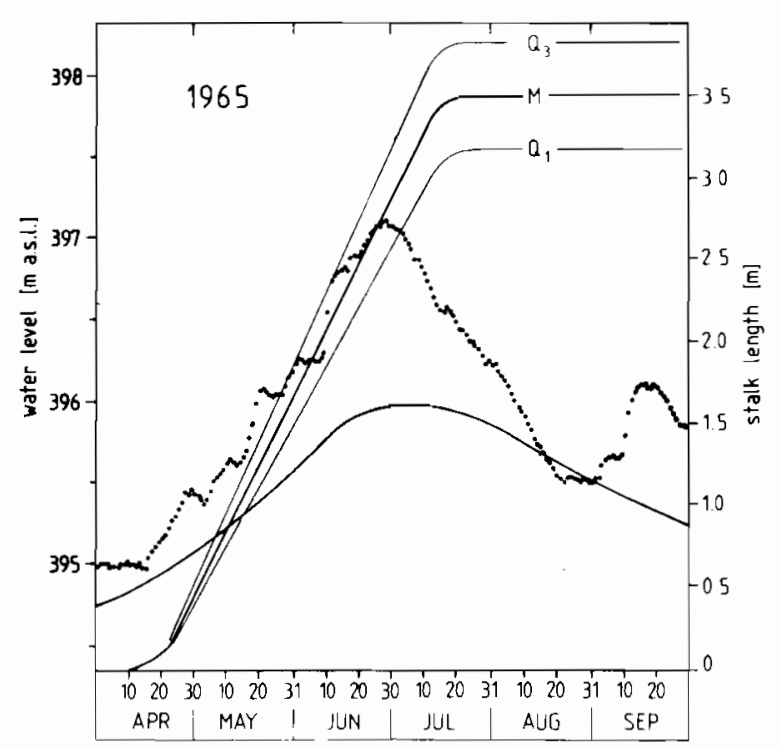

Fig. 3. Reed growth and water level from April to September 1965 $M, Q_{1}, Q_{3}$-expected growth curve of Phragmites stalks within a stand at an altitude of 394.35 m a.s.l.: $M$ - mean, $Q_{1}-25 \%$ quartile, $Q_{3}-75 \%$ quartile, $t_{0}=110$ days, $\dot{\mathbf{L}}=4.0 \mathrm{~cm} \mathrm{~d}^{-1}$, dotted line - water level, daily records; solid line - water level, monthly means, average of the years 1931 to 1980 
Comparing the water level curve and the growth curve, we see that $50-75 \%$ of all stalks could have been submerged for several weeks, especially in the first half of June. Flooding for 2 days or more can endanger the survival of a reed stalk and its rhizomes. The effect of the flooding was accentuated by two heavy and prolonged hailstorms, with wind velocities up to 7 on the Beaufort scale. Some newspaper photos, taken in mid-June 1965, show the flood damage to the reeds, and hence demonstrate the validity of this estimation.

It is concluded that the combination of flooding and mechanical damage by waves (and drifting matter) has been responsible for the reed decline in Lake ConstanceUntersee, rather than the nutrient load, which was relatively low at that time. However, some further detrimental factors need to be considered for a completely satisfying explanation of the reed decline in Lake ConstanceUntersee (Ostendorp 1990).

\section{High Water in 1987}

The maximum water level in 1987 was almost as high as in 1965 , but came 6 weeks later. Hence, the reeds were affected in a different way (Fig. 4). Firstly, the present reed front was now at an altitude of about $394.50-394.70 \mathrm{~m}$ a.s.l. because of the decline in 1965 and the following years. Secondly, the high water levels occurred 1 month later, when the reed culms were fully grown. Thirdly, no storms, hail or drifting matter accompanied the flood. Hence, no serious damage to lakeside reeds was found.

\section{Susceptibility of winter-mown reed stands to high water levels}

Full grown stalks of winter-mown or winter-burned reeds are on average thinner and shorter, and their bio-

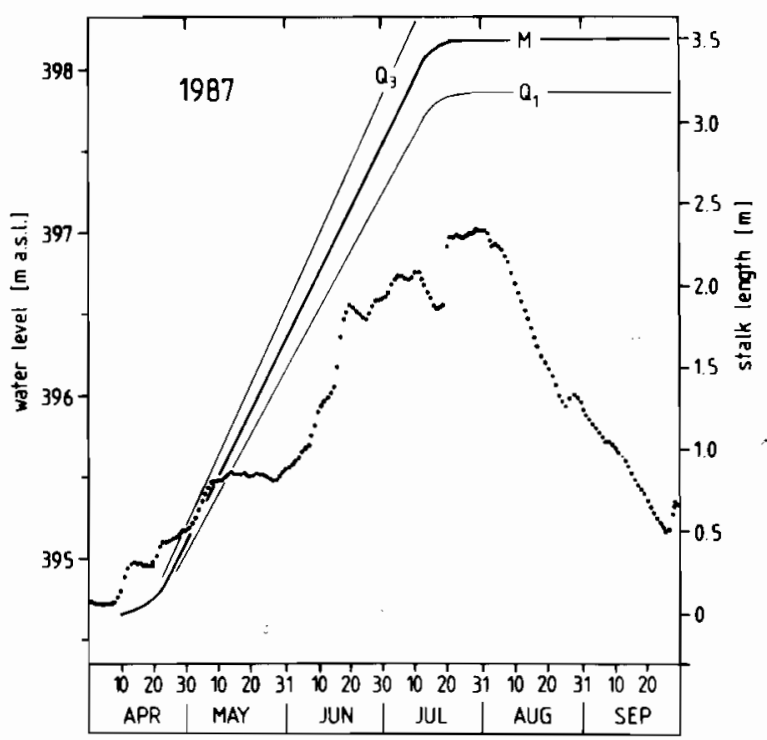

Fig. 4. Reed growth and water level from April to September 1987 (reed stand at an altitude of $394.60 \mathrm{~m}$ a.s.l.; see also Fig. 3)

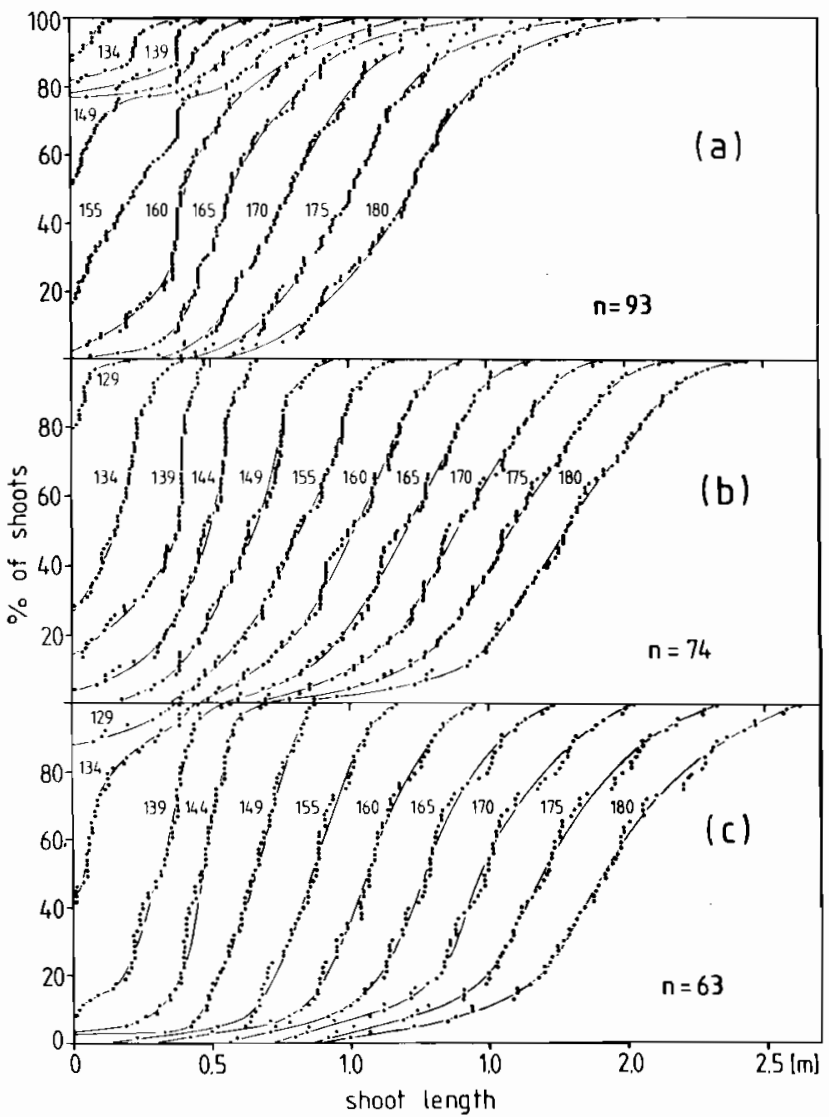

Fig. 5. Frequency distributions of the critical shoot length $L_{\text {crit }}$ of a a stand mown in the previous winter, $\mathbf{b}$ a stand not mown in the previous winter but mown the winter before, $\mathrm{c}$ a stand untreated for several years; 134 th day $=13$ May, 180 th day $=28$ June

mass is lower compared with stalks of untreated stands (Ostendorp 1987). They exhibit a lower growth rate and a shorter growth period. Hence, an average stalk of a mown stand is shorter at any time of the season, and consequently its susceptibility to high waters is greater. A quantitative estimation is possible if the following information is available:

I. The parameters of the $L_{\text {crit }}$ frequency distribution at different points of the season (Fig. 5), and

2. the frequency distributions of water levels at different dates (Fig. 2).

Using Fig. 5 and 2, we can estimate the percentage of submerged stalks, depending upon water level frequency distribution.

Say that the three stand types (A - mown the previous winter, $\mathrm{B}-$ mown the winter before, $\mathrm{C}-$ untreated) are at the same altitude, i.e. $395.0 \mathrm{~m}$ a.s.l. Considering the probability of submergence of $p=0.2$ (i.e. flooding in 2 of 10 years on average), in May nearly all stalks in each stand will be critically submerged (Fig. 6). From the beginning of June onwards the three stand types differ: in A ca. $80 \%$ of all stalks will be flooded whereas the proportion drops to $10-30 \%$ in stands B and C. If $p$ increases $(p=0.5$, and $p=0.8$, i.e. submergence in every second year, and in 8 of 10 years, respectively), the proportion of flooded stalks decreases in all stands. 

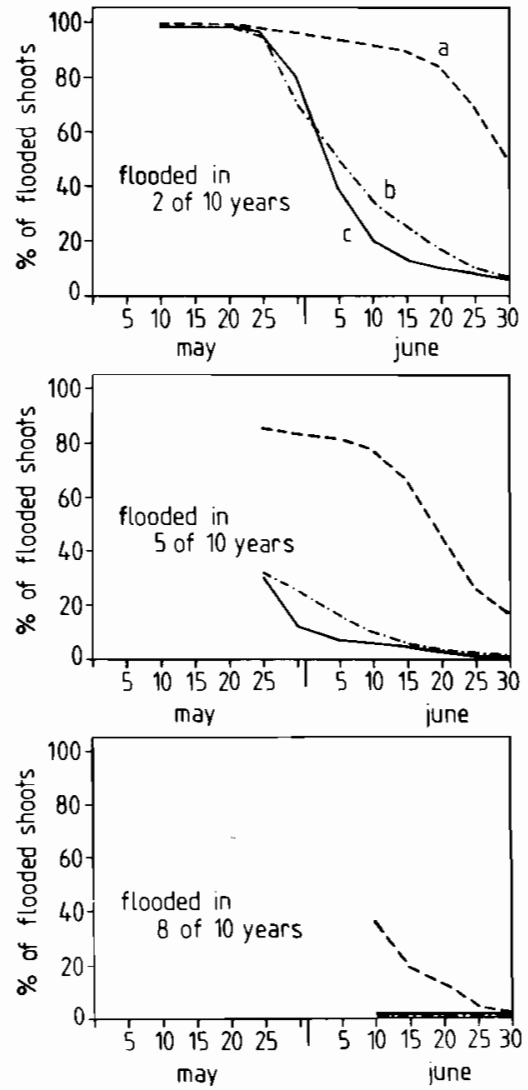

Fig. 6. Probability of flooding (in 2, 5, and 8 of 10 years) and percentage of critically submerged shoots in $a$ a winter mown reed stand, $b$ a reed stand untreated in the last winter, and $c$ a reed stand which has not been treated for a long time; the time span for which the graphs are not defined covers the time when the young sprouts are leafless and submergence is irrelevant (see text)

However, when $p$ is high, the submergence in untreated stands is negligible, but proportion of flooded stalks is remarkably high in the mown stand A. Based on this model, it is concluded that winter mowing management of lakeside reeds increases the risk of flooding and conse- quent dieback of a significant proportion of stalks, thereby damaging the reed stand.

\section{Discussion}

Phragmites exhibits a precise stalk geometry in for instance the cone-like shape of its stem, the leaf number, the internodal length (Haslam 1970, 1971). The growth characteristics are equally simple: the growth rate of an individual stem is a linear function of time, and the period of growth is a function of the basal diameter of the stalk. Hence, it seems that the growth of a stalk is controlled by "internal" factors, weather conditions being of minor importance.

The simplicity of the stand architecture facilitates the application of numerical models which can give some insight into rhizome-stem interrelations, to nutrient mobilization from the deeper lying storage rhizomes, to internal stand structure regulation, to the nutrient economy, and to the importance of insulation and temperature for the autogenous carbon supply of the culm, relative to the nutrient supply by the rhizome (Ostendorp, in prep.). However, these concepts need further evaluation.

In this paper the practical consequences may be summarized as follows:

1. If annual high water levels or aperiodic flooding are likely to be factors controlling the dynamic development of the reed fringe, their significance relative to other parameters can be estimated (Hagenmeyer and Krumscheid-Plankert 1990). In Lake Constance the lakeside reeds are generally increasing; however, if a high water event occurs early in the vegetation period, as in 1988, the amount of increase is low or even negative (i.e. retreat) (Fig. 7).

2. Various kinds of reed belt management can be studied, as to whether they improve or impair the reeds' tolerance to high water levels. In this paper, it can be stated that winter mowing of reeds leads to a increased proportion
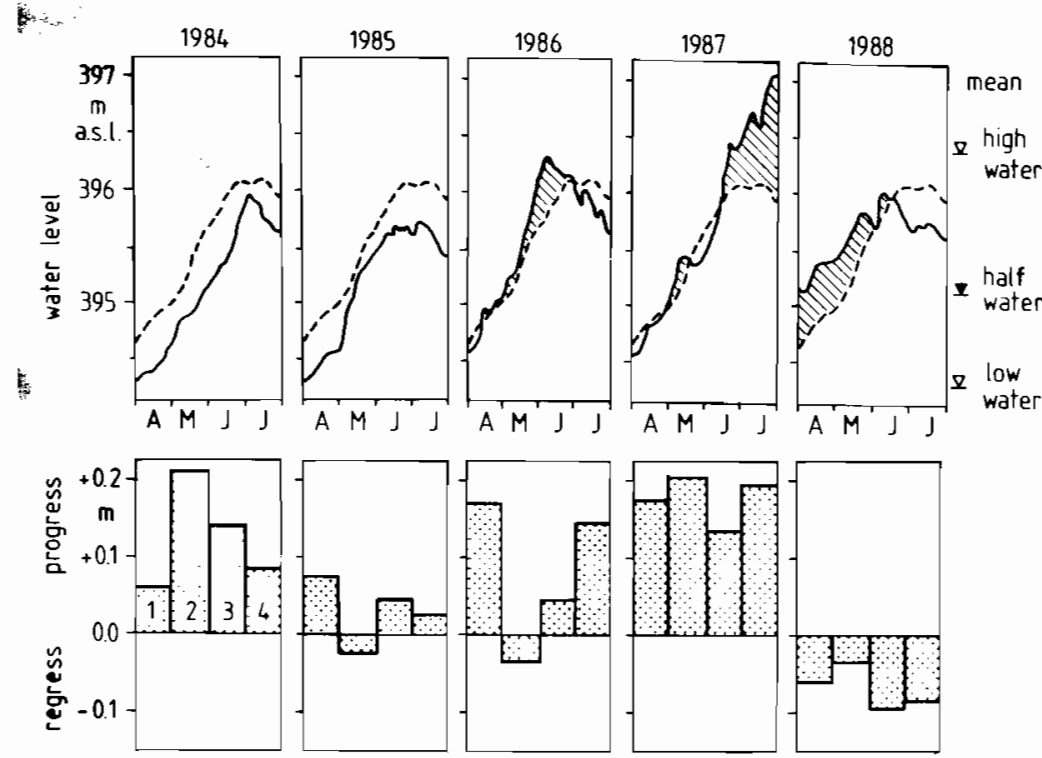

Fig. 7. Development of the lakeside reed front (regression or progress relative to the previous year) in Lake Constance-Untersee, demonstrated for 4 types of reed stands (data from A. Pier, pers. comm.); solid curve - actual water level, daily records; dashed line mean yearly course of the water level 
of submerged stalks compared with untreated reed stands; hence, mowing of the lakeside reed fringe can endanger their viability.

3. Optimisation of lake shore restoration works by means of reed plantations is facilitated. Bittmann (1968) recommended plantations of Phragmites no further down than the average high water level in summer, otherwise the young shoots would be drowned. However bank erosion is often most serious between the low water line and the mean water level, and thus Phragmites planted as a bank protection measure should be within this range. Furthermore, these permanently flooded reeds are of the greatest importance for the retention of nutrients and fish breeding.

\section{References}

Bittmann E (1968) Lebendbaumaßnahmen an Still- und Fließgewässern mit Ausnahme von Wildbächen. In: Buchwald $\mathrm{K}$, Engelhardt W (eds) Handbuch für Landschaftspflege und $\mathrm{Na}$ turschutz 4. Munich, pp 158-172

Brändle R (1983) Evolution der Gärungskapazität in flut- und anoxiatoleranten Rhizomen von Phalaris arundinacea, Phragmites communis, Schoenoplectus lacustris und Typha latifolia. Bot Helv 93:39-45

Brändle R (1985) Kohlehydratgehalte und Vitalität isolierter Rhizome von Phragmites australis, Schoenoplectus lacustris und Typha latifolia nach mehrwöchigem $\mathrm{O}_{2}$-Mangelstreß. Flora 177:317--321

Brändle R, Crawford R M M (1987) Rhizome anoxia tolerance and habitat specialization in wetland plants. In: Crawford R M M (ed) Plant life in aquatic and amphibious habitats. London, $397-410$

Etherington J R (1983) Wetland ecology. Studies in Biology vol 154, London

Hagenmeyer T, Krumscheid-Plankert P (1990) Schilfbestandsent- wicklung der natürlichen Uferschilfbestände im Bodenseekreis 1986-1989. Report of the Limnol. Inst. Universität Konstanz

Haslam S M (1970) The development of the annual population in Phragmites communis. Ann Bot 34:571-591

Haslam S M (1971) Shoot height and density in Phragmites stands. Hidrobiologia (Bucarest) 12:113-119

Lang $G$ (1968) Vegetationsänderungen am Bodenseeufer in den letzten hundert Jahren. Schr Ver Gesch Bodensee 86:295-319

Ostendorp W (1987) Die Auswirkungen von Mahd und Brand auf die Ufer-Schilfbestände des Bodensee-Untersees. Natur und Landschaft 62:99-102

Ostendorp W (1989) "Die-back" of reeds in Europe - a critical review of literature. Aquat Bot 35:5-26

Ostendorp W (1990) Die Ursachen des Röhrichtrückgangs am Bodensee-Untersee. Carolinea 48:85-102

Ostendorp W, Möller J (1991) The EM-Algorithm as a tool for structure analysis of stands of the Common Reed (Phragmites australis (Cav.) Trin. ex Steud.). Ecol Modelling (in press)

Peintinger M (1987) Schilfpflanzversuch Markelfingen 1986 - Wissenschaftliche Begleituntersuchung. Report of Deutscher Bund für Vogelschutz Konstanz

Rodewald-Rudescu L (1974) Das Schilfrohr. Die Binnengewässer vol 27, Stuttgart

Rudescu L (1965) Neue biologische Probleme bei den PhragmitesKulturarbeiten im Donaudelta. Arch Hydrobiol Suppl $30: 80-111$

Schröder R (1979) The decline of recd swamps in Lake Constance. Symp biol Hung 19:43-48

Schröder R (1987) Das Schilfsterben am Bodensee-Untersee, Beobachlungen, Untersuchungen und Gegenmaßnahmen. Arch Hydrobiol Suppl 76:53-99

Schwilch E (1963) Landschaftspflegeplan Pfäffiker See. Report of Institut für Landespflege und Landschaftsgestaltung, Technische Hochschule Hannover

Studer C, Brändle R (1984) Sauerstoffkonsum und - versorgung der Rhizome von Acorus calamus, Glyceria maxima, Menyanthes trifoliata, Phalaris arundinacea, Phragmites communis und Typha latifolia. Bot Helv 94:23-31

Yamasaki S, Tange (1981) Growth responses of Zizania latifolia, Phragmites australis and Miscanthus sacchariflorus to varying inundation. Aquat Bot 10:229-239 